\title{
Energy Efficient Approaches by Retrofitting Heat Pumps Water Heating System for a University Dormitory
}

\author{
Fujen Wang ${ }^{1, *} \mathbb{C}$, Kusnandar $^{2,3}$, Hungwen Lin $^{4} \mathbb{D}$ and Minghua Tsai ${ }^{1}$ \\ 1 Department of Refrigeration, Air Conditioning and Energy Engineering, National Chin-Yi University of \\ Technology, Taichung 411, Taiwan; ts00998117@yahoo.com.tw \\ 2 Graduate Institute of Precision Manufacturing, National Chin-Yi University of Technology, \\ Taichung 411, Taiwan; kusnandar11@gmail.com \\ 3 Department of Refrigeration and Air Conditioning Engineering, Politeknik Negeri Indramayu, \\ Indramayu 45214, Indonesia \\ 4 Green Energy and Environment Research laboratories, Industrial Technology Research Institute, \\ Hsinchu 310, Taiwan; lhw@itri.org.tw \\ * Correspondence: fjwang@ncut.edu.tw; Tel.: +886-922-836-010
}

check for updates

Citation: Wang, F.; Kusnandar; Lin, H.; Tsai, M. Energy Efficient Approaches by Retrofitting Heat Pumps Water Heating System for a University Dormitory. Buildings 2021, 11, 356. https://doi.org/10.3390/ buildings 11080356

Academic Editor: Fabrizio Ascione

Received: 22 June 2021

Accepted: 12 August 2021

Published: 16 August 2021

Publisher's Note: MDPI stays neutra with regard to jurisdictional claims in published maps and institutional affiliations.

Copyright: (c) 2021 by the authors. Licensee MDPI, Basel, Switzerland. This article is an open access article distributed under the terms and conditions of the Creative Commons Attribution (CC BY) license (https:// creativecommons.org/licenses/by/ $4.0 /)$.

\begin{abstract}
With the cost of energy rising, the value of conservation grows. Interest in energy efficiency could be a sound investment or a necessary public policy. Heat pump systems provide economical alternatives of recovering heat from different sources for use in various applications. The objective of this study is to present the strategic approach on the energy efficient analysis of the water heating system retrofitted by applying a heat pump system in the dormitory of a university. Energy savings were determined by comparing field measurements of water consumption, water temperature and power consumption of the overall system before (electric resistance heating system) and after (heat pump heating system) the implementation of this project. Furthermore, the building energy simulation code (eQuest) has been applied to verify and predict the long-term energy consumption for both water heating systems. The results from energy modelling revealed the good agreement for energy simulation and field measurement data and the improvement of energy efficiency and energy savings could be achieved satisfactorily by retrofitting of a heat pump system. The energy conversion efficiency of hot water for energy consumption at 0.63 (Mcal/Mcal) could be achieved after the application of heat pump water heating system. It also presented the annual saving about USD 20,000 (NTD 600,000) for the dorm by using a heat pump heating system under the electrical billing rate of Taiwan.
\end{abstract}

Keywords: heat pump; water heating system; field measurement; energy modeling

\section{Introduction}

The increasing cost of fuel and global warming attention necessitate a constant reevaluation of the water heating system even in a tropical area. Heat pump heating systems provide economical alternatives by recovering heat from different sources in various applications. A comprehensive review of the various methods for improving the performance of heat pump was investigated [1]. Many hybrid heat pump systems suitable for different applications with various heat sources have been reported as well. Franco [2] analyzed the optimal sizing of a particular solution for renewable energy residential building integration by combining a photovoltaic (PV) plant with a heat pump. Moreover, Berntsson [3] extensively discussed the heat sources for the heat pump application of building and industry in Sweden from the aspects of technology, economy and environment. Okamoto [4] investigated a heat pump system with a latent heat storage utilizing seawater installed in an aquarium. Osterman [5] presented an extensive review of different kinds of heat pump system for the heating and cooling of buildings with a focus on heat pumps with thermal energy storage. Furthermore, the measurement of the energy performance of 
air-to-water and water-to-water heat pumps in hotel applications in subtropical climates has been investigated [6]. The results presented heat pumps were financially feasible with payback period of about two years.

Computer-based simulation is widely accepted by many studies as a powerful tool for evaluating building energy consumption [7]. Felius [8] also applied energy simulationbased optimization to explore energy efficiency in residential buildings by upgrading the smartness of retrofitting packages towards energy-efficient buildings in cold climate countries. eQuest [9] is a sophisticated, yet easy to use, energy simulation tool developed by doe2.com. It is also a freeware building energy tool that provides professional-level results with affordable effort. Zhu [10] used eQuest as a simulation tool to determine the optimum solution for facility engineers and to evaluate different energy conservation alternatives. A comprehensive review presents that the modelling and simulation of energy-related human-buildings interaction play an essential role in predicting the actual energy use of a building operation [11]. Furthermore, Yezioro [12] presented an approach using artificial neural networks for predicting building energy performance. Ascione [13] studied the accurate simulation of energy performance to design a low energy building using EnergyPlus. Some building simulation tools including eQuest and EnergyPlus have been selected to compare the results in predicting energy consumption. Choi [14] used six simulation tools to investigate the correlation of energy use intensity between 15 residential projects. As a result, numerical simulations were carried out to assess the energy saving for heating and cooling for several international locations. Many novel technologies to enhance energy performance and the indoor environmental quality of buildings has been investigated extensively [15].

A thermal modeling and economic analysis of gas engine heat pump for building has been presented by Sanaye [16]. Approaches including the annual cost of energy consumption and the payback period were applied in the economic analysis. Moreover, the economy of utilizing heat from low-temperature geothermal sources using a heat pump has been investigated [17]. The coefficient of profitability and the payback year was evaluated comprehensively. Furthermore, a thermal model within building energy system optimization using a ground source heat pump was investigated by Miglani [18]. A substantial energy saving could be achieved by comparison to conventional electric boilers. The measurements needed to perform the diagnosis are an analyzed opportunity to reduce the energy needed in buildings. Moreover, business models combining heat pumps and district heating in buildings can be profitable, which will achieve maximum cost saving of $33 \%$ and emission savings of $75 \%$ [19]. In addition, Bellanco [20] also presented an extensive review about the fault behavior of heat pumps and measurement methods including various virtual sensors.

In this study, the energy saving analysis of water a heating system retrofitted by using heat pumps in the dorm of a university was presented. The energy savings after the retrofitting of a heat pump water heating system were determined through field measurement and building energy simulation as well. The long-term energy consumption data can be obtained after the verification of energy modelling. The energy conversion efficiency of hot water for energy consumption will be presented and the annual saving will be analyzed after the retrofitting application of a heat pump water heating system.

\section{Methodologies}

\subsection{System Description}

The investigated building is a dormitory for female students in a university campus located in a central part of Taiwan with subtropical weather conditions. This dorm accommodated about 500 students from second floor to ninth floor. There are 15 rooms with the dimensions of $6.7 \mathrm{~m}$ length and $3.5 \mathrm{~m}$ width on each floor. Two electrical water heaters $(42.1 \mathrm{~kW})$ and a hot water storage tank $\left(8.7 \mathrm{~m}^{3}\right.$ of tank \#5) at the roof provide the shower water for each floor. Tank \#5 is the existing one for the previous electrical heater system. Tanks \#1-4 are additional ones specifically for heat pump heating system on hot 
water storage mode during off-peak demand. The schematic diagram of the water heater system is shown in Figure 1. Two supplementary electrical heaters (type A of $9.45 \mathrm{~kW}$ and type $\mathrm{B}$ of $12.1 \mathrm{~kW}$ ) at each floor were equipped in the public shower room with $70{ }^{\circ} \mathrm{C}$ cut-in temperature.

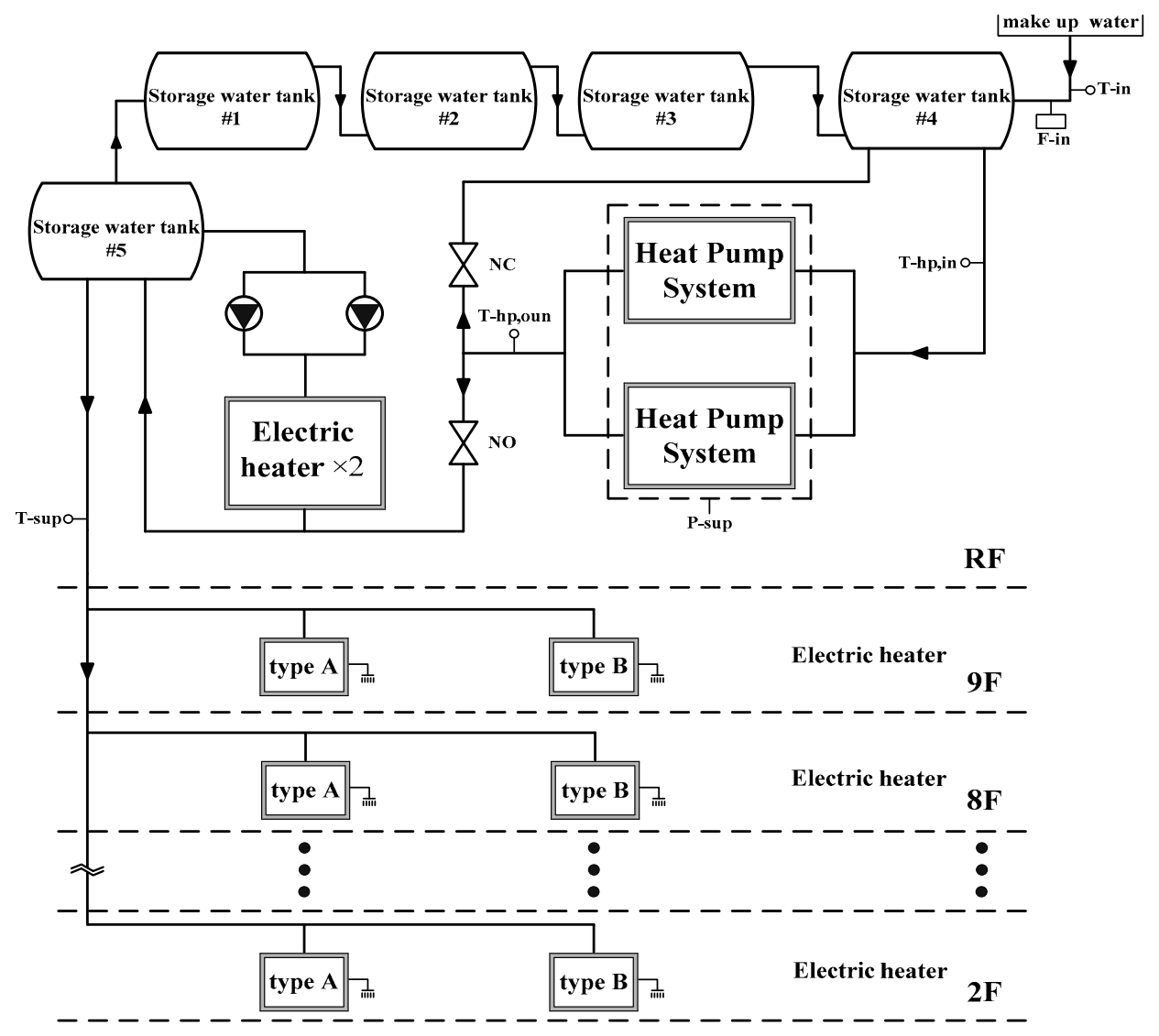

Figure 1. Schematic diagram of the investigated water heating system.

Due to the increasing cost of electricity and unaffordable bills from the power company, the heat pump water heating system was introduced to provide an economical alternative for hot water supply. The schematic diagram of the newly constructed air-source heat pump system is also displayed in Figure 1 (dashed line). Typically, the water heating system consists of the heat pump module with two air-source heat pump units and four water storage tanks of $5 \mathrm{~m}^{3}$ capacity (tank \#1 to \#4). Each heat pump unit has $27.7 \mathrm{~kW}$ nominal power consumption, which can provide $74.4 \mathrm{~kW}$ for heating capacity and $39.8 \mathrm{~kW}$ for cooling capacity. The heat pump water heating system was incorporated into the original electrical heater system in series to provide the base load demand for hot water supply in the dorm, while the electrical heating system served as the backup system when the ambient temperature was too low. Set point temperature for hot water supply to manipulate the heat pump system was remained at $50{ }^{\circ} \mathrm{C}$ operating range.

\subsection{Field Measurement}

To evaluate the energy saving performance, comprehensive field measurements including water temperature variation, water consumption and energy consumption $(\mathrm{kWh})$ were carried out for one month before and after the installation of heat pump heating system. Field tests were conducted not only to provide reliable baseline data for comparison but also to verify the energy modeling results for assessment of performance improvement and energy saving potential. 
The hot water consumption in a typical floor was monitored and recorded by using a built-in digital water flow meter (F-in) with an accuracy of $0.2 \%$. The variation of temperature at the outlet of supply water and return water was recorded through built-in PT-100 sensors at an accuracy of $0.2^{\circ} \mathrm{C}$. The power consumption of electrical heater system was measured using a power meter with an uncertainty of $0.2 \%$ of full scale. After the retrofitting of heat pump water heating system, a building energy management system (BEMS) was established to record the water temperature at different locations and the power consumption of the overall system continuously.

To assess the energy saving after the retrofitting of heat pump heating system, both the water temperature variation and power consumption have been recorded simultaneously using data logger and power meter in every $5 \mathrm{~min}$ for one month before and after installation. Then, the baseline of energy cost $\mathrm{F}_{\text {base }}(\mathrm{NTD} / \mathrm{kWh})$ using electrical heater can be expressed as follows:

$$
\mathrm{F}_{\text {base }}=\frac{\sum_{1}^{\mathrm{n}}\left(\mathrm{Q}_{\mathrm{f}-\mathrm{h}} \times \mathrm{U}_{\mathrm{f}}\right)}{\sum_{1}^{\mathrm{n}}\left\{\left[\mathrm{V}_{\mathrm{c}} \times\left(\mathrm{T}_{\mathrm{h}}-\mathrm{T}_{\mathrm{c}}\right)\right] \times \rho_{\mathrm{w}} \times \mathrm{C}_{\mathrm{pw}} \times \mathrm{HV}_{\mathrm{f}}^{-1}\right\}}
$$

where $Q_{\mathrm{f}-\mathrm{h}}$ is the energy consumption of electrical heater $\left(\mathrm{kWh} /\right.$ day), $\mathrm{U}_{\mathrm{f}}$ is the electricity cost $(\mathrm{NTD} / \mathrm{kWh})$ based on the exchange rate of $1 \mathrm{USD}=30 \mathrm{NTD}, \mathrm{Vc}_{\mathrm{c}}$ is the water consumption $\left(\mathrm{m}^{3} /\right.$ day), $\mathrm{T}_{\mathrm{c}}\left({ }^{\circ} \mathrm{C}\right)$ and $\mathrm{T}_{\mathrm{h}}\left({ }^{\circ} \mathrm{C}\right)$ represent the average inlet and outlet water temperature of electrical heater, respectively, $\rho_{\mathrm{w}}$ is the density of water, $\mathrm{C}_{\mathrm{pw}}$ is the specific heat of water, $\mathrm{n}$ is total number of rooms and $\mathrm{HV}_{\mathrm{f}}$ is the heating values of energy $(\mathrm{kJ} / \mathrm{kWh})$.

Therefore, the baseline of energy efficiency ratio of hot water production $\mathrm{E}_{\text {base }}(\mathrm{kWh} / \mathrm{kWh})$ using electrical heater can be obtained by the following:

$$
\mathrm{E}_{\text {base }}=\frac{\sum_{1}^{\mathrm{n}} \mathrm{Q}_{\mathrm{f}-\mathrm{h}}}{\sum^{\mathrm{n}}\left\{\left[\mathrm{V}_{\mathrm{c}} \times\left(\mathrm{T}_{\mathrm{h}}-\mathrm{T}_{\mathrm{c}}\right)\right] \times \rho_{\mathrm{w}} \times \mathrm{C}_{\mathrm{pw}} \times \mathrm{HV}_{\mathrm{f}}^{-1}\right\}}
$$

Similarly, the baseline of energy cost Fpost (NTD/kWh) using heat pump can be expressed as follows:

$$
\mathrm{F}_{\text {post }}=\frac{\sum_{1}^{\mathrm{D}}\left(\mathrm{Q}_{\mathrm{e}-\mathrm{d}}+\mathrm{Q}_{\mathrm{f}-\mathrm{h}}\right) \times \mathrm{U}_{\mathrm{f}}}{\sum_{1}^{\mathrm{D}}\left\{\left[\mathrm{V}_{\mathrm{c}} \times\left(\mathrm{T}_{\mathrm{h}}-\mathrm{T}_{\mathrm{c}}\right)\right] \times \rho_{\mathrm{w}} \times \mathrm{C}_{\mathrm{pw}} \times \mathrm{HV}_{\mathrm{f}}^{-1}\right\}}
$$

where $\mathrm{D}$ (day) is the measured days and $\mathrm{Q}_{\mathrm{e}-\mathrm{d}}(\mathrm{kWh} /$ day) is the power consumption using heat pumps.

Thus, the baseline of energy efficiency ratio of hot water production Epost $(\mathrm{kWh} / \mathrm{kWh})$ using heat pump can be obtained by the following:

$$
\mathrm{E}_{\text {post }}=\frac{\sum_{1}^{\mathrm{D}}\left(\mathrm{Q}_{\mathrm{e}-\mathrm{d}}+\mathrm{Q}_{\mathrm{f}-\mathrm{h}}\right)}{\sum_{1}^{\mathrm{D}}\left\{\left[\mathrm{V}_{\mathrm{c}} \times\left(\mathrm{T}_{\mathrm{h}}-\mathrm{T}_{\mathrm{c}}\right)\right] \times \rho_{\mathrm{w}} \times \mathrm{C}_{\mathrm{pw}} \times \mathrm{HV}_{\mathrm{f}}^{-1}\right\}}
$$

\subsection{Energy Modeling}

To predict the long-term power consumption of this retrofitted heat pump water heating system, the energy modeling by using eQuest was conducted based on all of the existing building information. The simulation model was created from the building parameters (see Table 1) and characteristics obtained from a building survey, documentations and 
drawings. Verification of the simulation model with actual on-site measurement electricity data has been conducted as well. To create the building model for the eQuest simulation, a geometric model of the investigated dorms was created and is shown in Figure 2. The water heating systems, including both electrical heater and heat pump system, were modeled and sketched using the eQuest application accordingly.

The weather data of typical meteorological years (TMY) were adopted to conduct energy simulation. To simplify the model simulation, multipliers were used for typical floors and rooms in the dorms. An averaging approach based on the percentage of a thermal zone area to the total floor area was adopted while calculating internal loads. Typical input parameters for energy simulation are shown in Table 2. These parameters include the capacity of $257 \mathrm{~kW}$ (with tank volume $10.22 \mathrm{~m}^{3}$ ) for electric heater and $55 \mathrm{~kW}$ for heat pump (with tank volume $29.53 \mathrm{~m}^{3}$ ). The electricity input is ratio 1.0526 for heaters and 0.3722 for heat pump, respectively, with domestic hot water of the loop type.

The design temperature of hot water at $70{ }^{\circ} \mathrm{C}$ for both electrical heater and at $53{ }^{\circ} \mathrm{C}$ for heat pump system, while storage tanks were located outside with the insulation loss of overall heat transfer coefficient UA at $0.595 \mathrm{~kW} /{ }^{\circ} \mathrm{C}$. Moreover, the model was assessed based on 2011 electricity bill data. Verification of energy modelling has been conducted and compared to actual field measurement data and actual power consumption data from BEMS along with bills data to assess the variation of energy consumption.

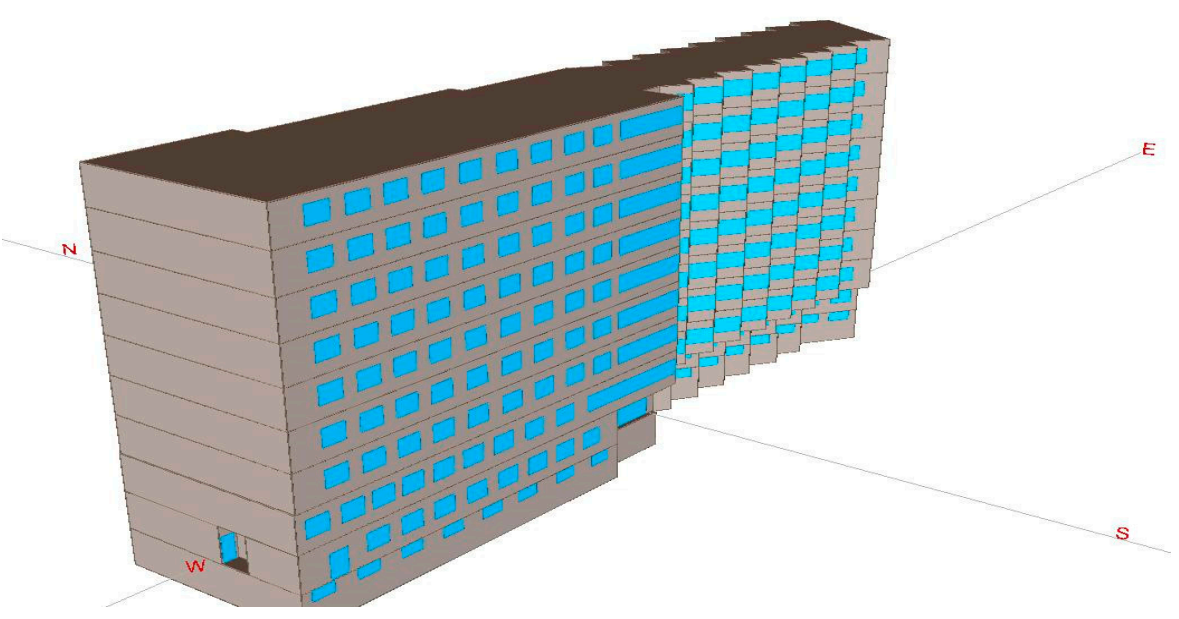

Figure 2. Building geometric model for energy modeling.

Table 1. Typical input parameters of building for building simulation.

\begin{tabular}{cc}
\hline Building Type & School, College/University \\
\hline Weather File & Taichung \\
Roof Surfaces & \\
Construction & Metal Frame, $>$ 24in. \\
Exterior finish/color & Roof, built-up Medium \\
Exterior Insulation & 3 in. polyurethane (R-18) \\
Above Grade Walls & \\
Construction & Metal Frame, $>24$ in. \\
Exterior Finish/Color & Stucco/Gunite Medium \\
Exterior Insulation & $\frac{3}{4}$ in. fiber \\
Additional Insulation & R-19 batt \\
Ground Floor & 12in. Concrete \\
\hline
\end{tabular}


Table 2. Typical input parameters of equipment for building simulation.

\begin{tabular}{ccc}
\hline Parameter & Heater & Heat Pump \\
\hline Capacity & $257 \mathrm{~kW}$ & $55 \mathrm{~kW}$ \\
Elec. Input ratio & 1.0526 & 0.3722 \\
Tank volume & $10.22 \mathrm{~m}^{3}$ & $29.53 \mathrm{~m}^{3}$ \\
Tank UA & $0.595 \mathrm{~kW} /{ }^{\circ} \mathrm{C}$ & $0.595 \mathrm{~kW} /{ }^{\circ} \mathrm{C}$ \\
Location & Zone & Outdoor \\
Loop type & Domestic Hot Water & Domestic Hot Water \\
Design hot water temp. & $70^{\circ} \mathrm{C}$ & $53^{\circ} \mathrm{C}$ \\
Max tank temp. & - & $55^{\circ} \mathrm{C}$ \\
\hline
\end{tabular}

\section{Results and Discussion}

The baseline for power consumption for the electrical heater system can be conducted according to the on-site measurement. Figure 3 displays the typical measurement data of water consumption, temperature variation and energy consumption for the electrical heater system from 11:00 a.m. to 11:00 a.m. of the next day $(24 \mathrm{~h})$. All of the data were acquired simultaneously every $5 \mathrm{~min}$ from data loggers during the $24 \mathrm{~h}$. As shown in Figure 3a, the peak hour for shower water consumption is from 4:00 p.m. to 11:30 p.m., which reflects the most common time for shower in the dorm. However, there exists water consumption in the morning (say 8:00 a.m.) and even scatters over the $24 \mathrm{~h}$, which reveals the diverse individual behavior for showering in this dorm. Moreover, the temperature variation for make-up water and supply hot water is presented in Figure 3b. The dashed line represents the make-up water at the steady temperature of $20^{\circ} \mathrm{C}$, while the solid line displays the dramatic fluctuation of the supply water temperature from the electrical heater system ranging from 65 to $75{ }^{\circ} \mathrm{C}$, which reveals an unstable supply water temperature and potential energy saving opportunity for the electrical heater system. Furthermore, as shown in Figure 3c, the power consumption peaks during 4:30 p.m. to 12:00 p.m., which corresponds with the higher water consumption in Figure 3a. However, there still exists a higher frequency for power consumption during the off-peak shower time, which reveals water tank insulation and piping heat loss should be improved.

All of the above-mentioned insulation and piping heat loss for energy consumption have also been taken into account for energy modeling assessment. After the retrofitting project of the heat pump water heating system, field measurement has been conducted through the building energy management system for long term data acquisition. Figure $4 \mathrm{a}$ presents the water consumption of the heat pump water heating system. The water consumption could be recorded every $5 \mathrm{~min}$ for $24 \mathrm{~h}$. The peak hour for water consumption of this heat pump system is about 4:30 p.m. to 12:00 p.m., which is quite similar to the electrical heater system. Moreover, the temperature variation of the make-up supply water and the return water is shown in Figure $4 \mathrm{~b}$. The make-up water temperature is about $20^{\circ} \mathrm{C}$, which is similar to the electrical heater system, while the supply hot water temperature ranging from 55 to $57^{\circ} \mathrm{C}$ reveals a more stable temperature of the hot water supply and the lower water supply temperature for energy saving concern. Furthermore, the power consumption for the heat pump system is shown in Figure 4c, which corresponds to the peak water consumption period. Even though there still exists some unexpected operation for heat pump during the off-peak shower period, the frequency is not as high as it is in the case of electrical heater system shown in Figure 3c. It reveals the insulation for the water storage tank and piping system for the heat pump system has been improved and can be conducted easily due to the lower supply temperature. 


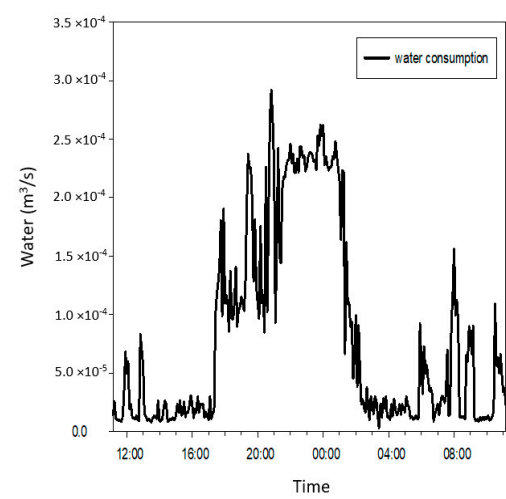

(a) Water consumption

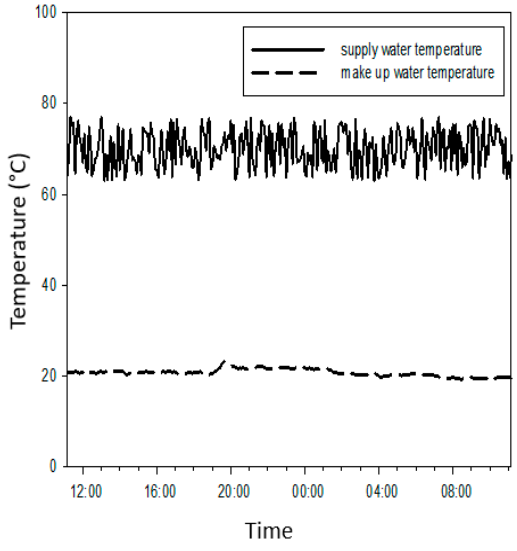

(b) Temperature variation

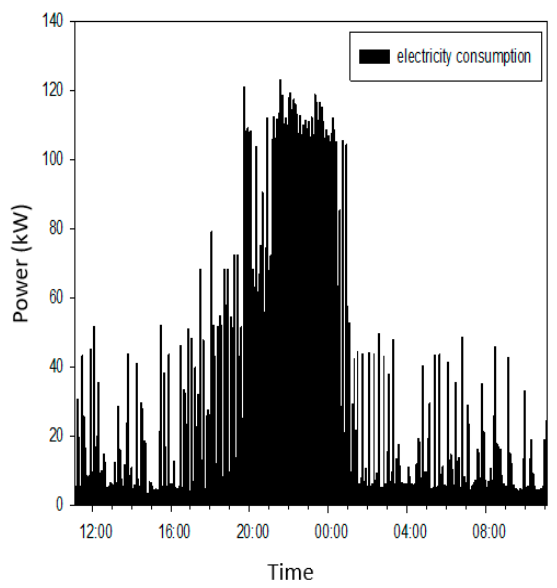

(c) Power consumption

Figure 3. Electrical heater water heating system.

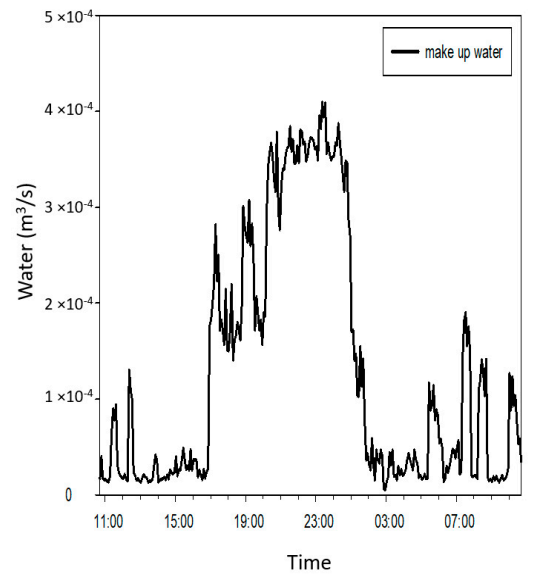

(a) Water consumption

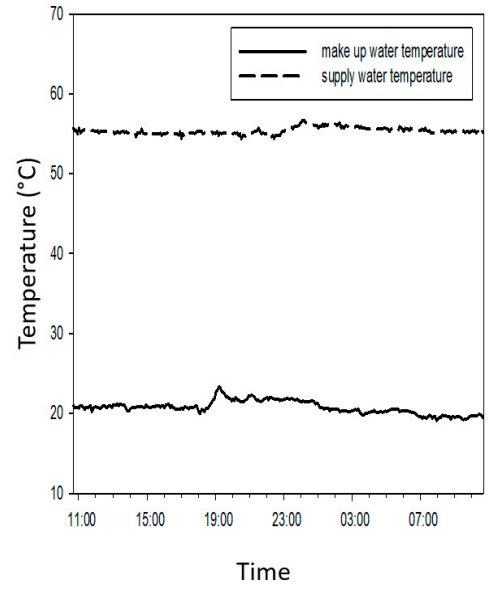

(b) Temperature variation

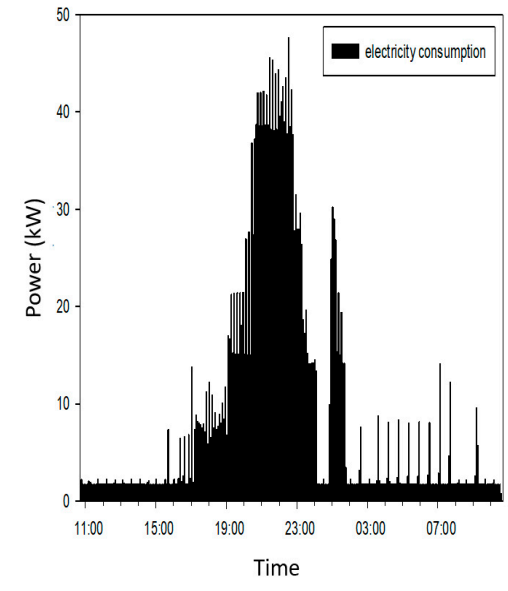

(c) Power consumption

Figure 4. Heat pump water heating system.

The long-term energy consumption data can be obtained after the verification of energy modelling. Energy modeling for the dorm has been conducted using eQuest simulation to evaluate the energy consumption of the water heating system. As shown in Figure 5, the energy consumption simulation presents a good agreement with field measurement data for 30 days. The peak for energy consumption occurs during weekdays and the off-peak period happens in the weekend, periodically. The peak demand using field measurement reaches $1000 \mathrm{kWh}$, while it comes to $940 \mathrm{kWh}$ using the energy consumption simulation. The off-peak demand using field measurement reaches $950 \mathrm{kWh}$, while it comes to $770 \mathrm{kWh}$ using the energy consumption simulation. The annual energy consumption data could be obtained for both the electrical heater system and the heat pump system accordingly with acceptable errors less than $10 \%[14]$. 


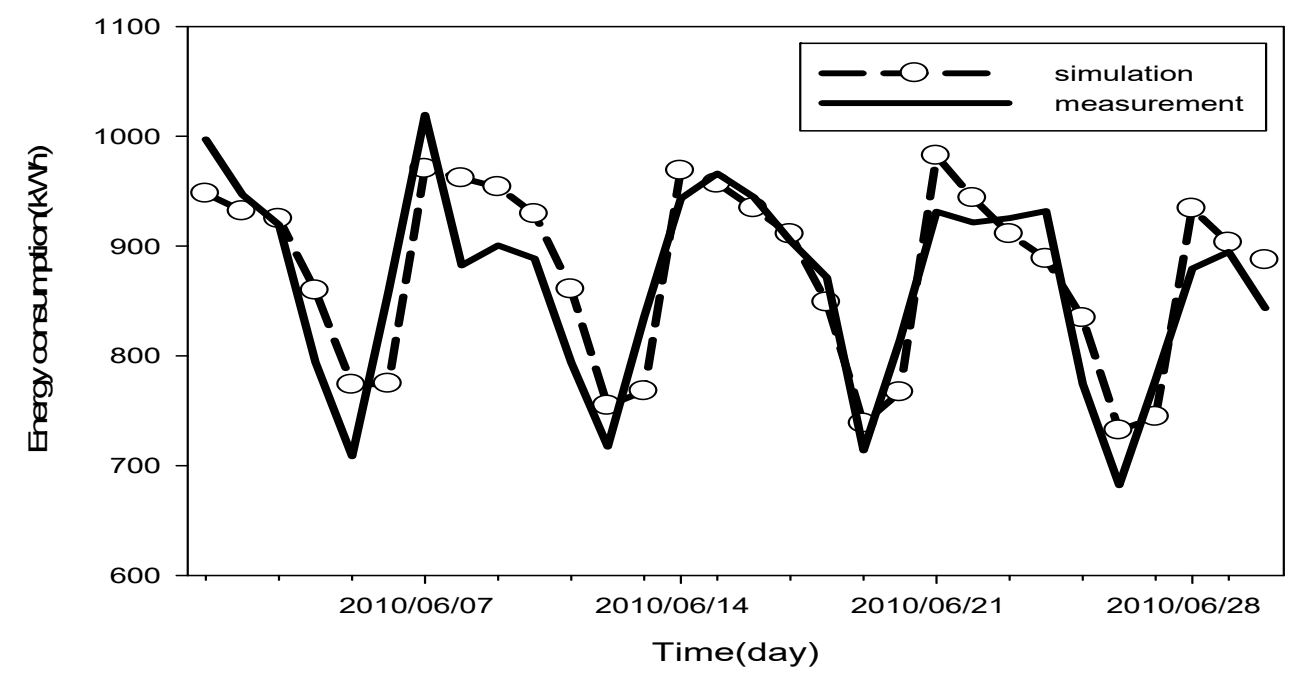

Figure 5. Verification of energy modeling with field measurement data.

The energy consumption (electricity) and total heating value of hot water production (thermal energy) for the electrical heater system and the heat pump system is shown in Figure $6 \mathrm{a}, \mathrm{b}$, respectively. It is quite obvious for the electrical heater system to have a higher energy consumption than that of the heat pump water heating system. A lower energy consumption along with a lower heating capacity requirement could be found in February (winter vacation) and from July to August (summer vacation).

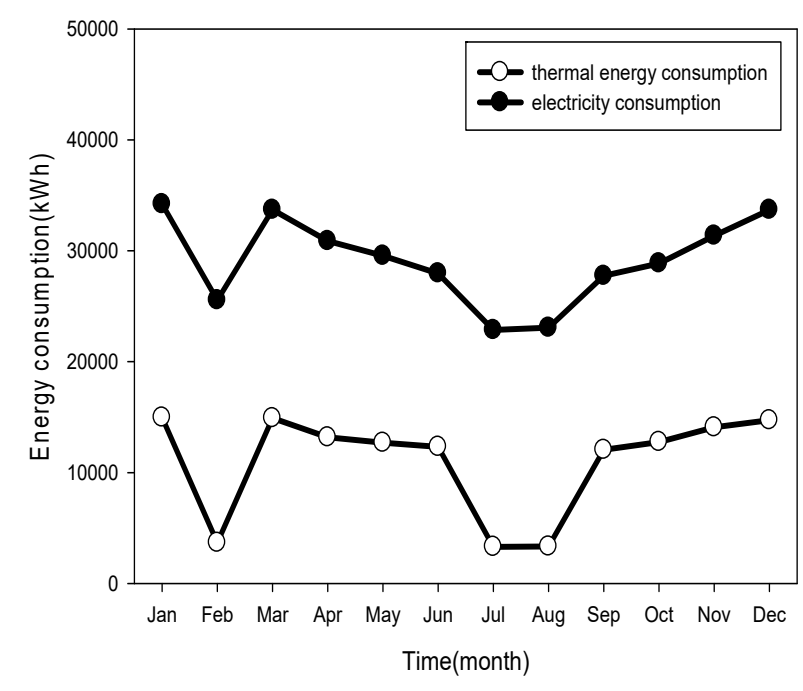

(a) Electric heater

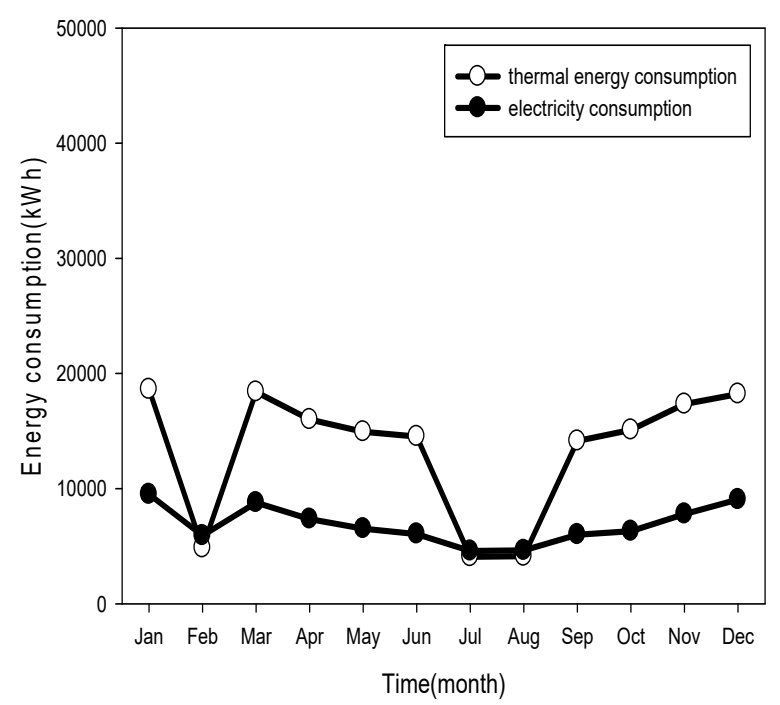

(b) Heat pump

Figure 6. Heat pump water heating system.

Moreover, the monthly energy efficiency ratio (E) and energy cost (F) for both the electrical heater system and the heat pump water heating system are presented in Figure 7. Figure $7 \mathrm{a}$ demonstrates that the average energy efficiency ratio for the electrical heater system $(\mathrm{E}=3.44 \mathrm{Mcal} / \mathrm{Mcal})$ is much lower than that of the heat pump system $(\mathrm{E}=0.63 \mathrm{Mcal} / \mathrm{Mcal})$ in Figure $7 \mathrm{~b}$. The lower water consumption during both winter vacation (February) and summer vacation (July to August) will degrade the energy conversion efficiency and increase the energy cost for both the electrical heater and the heat pump system. Moreover, Figure 7a also presents that the average energy cost for the electrical heater system $(\mathrm{F}=9.86 \mathrm{NTD} / \mathrm{Mcal})$ is much higher than that of the heat pump system $(\mathrm{F}=2.58 \mathrm{NTD} / \mathrm{Mcal})$ 
in Figure $7 \mathrm{~b}$. It also reveals the energy cost could be reduced obviously by the retrofitting of a heat pump water heating system. A different set point for the hot water temperature is suggested for running cost saving concern during off-peak months [19]. Furthermore, the energy cost saving at an average of about $60 \%$ also presented an annual saving of about USD 20,000 for the dorms by using a heat pump water heating system under the electricity billing rate of Taiwan. The overall budget for this retrofitting project is about USD 42,000 (NTD 1,260,000). The simple payback calculation is about 2.1 years, which is financially feasible and similar to the literature [6].

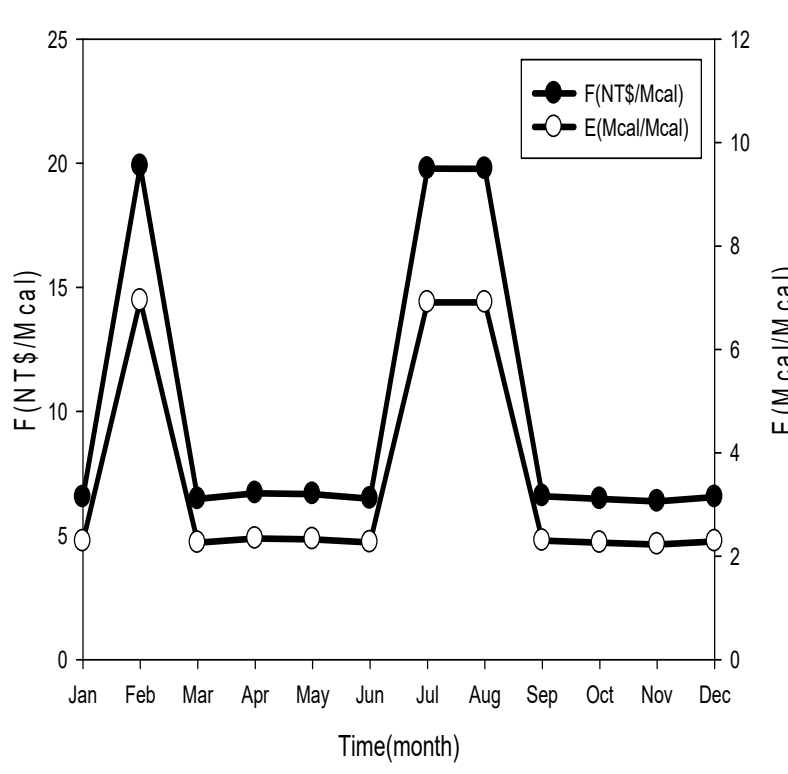

(a) Electric heater

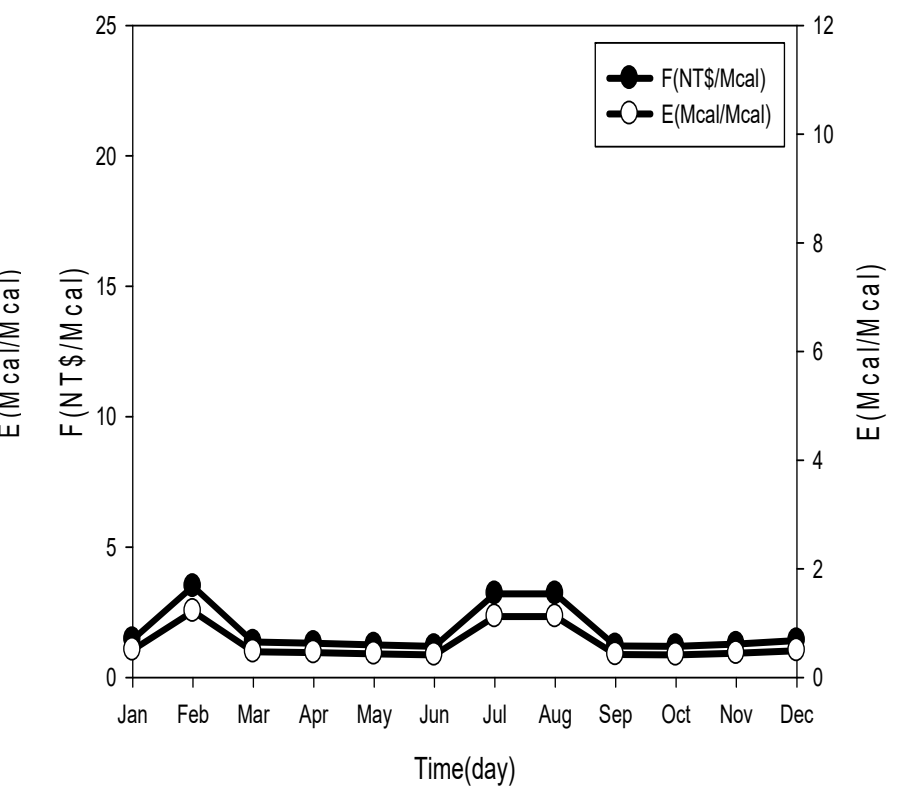

(b) Heat pump

Figure 7. Energy efficiency ratio and energy cost.

\section{Conclusions}

The increase in energy costs necessitates the re-evaluation of water heating system needs for most of the dormitories on the university campus of Taiwan. To present a strategic approach on the energy saving analyses of the water heating system through the retrofitting of a heat pump water heating system in the dormitory of a university, field measurements of water consumption, water temperature and power consumption of the overall system have been conducted comprehensively. An energy modelling tool has been applied to satisfactorily verify and predict the long-term energy consumption after verification with field measurement data. The energy conversion efficiency as well as the energy cost of an electrical heater water heating system could be improved substantially after the retrofitting of a heat pump water heating system. It also presented a considerable annual saving for energy cost by using a heat pump heating system under the electrical billing rate of Taiwan. A more robust investigation for an energy-efficient and cost-effective heat pump heating system could be expected accordingly.

Author Contributions: Conceptualization, F.W. and K.; methodology, H.L.; software, M.T.; validation, M.T.; formal analysis, F.W. and K.; investigation, H.L.; resources, F.W. and K.; data curation, M.T. and H.L.; writing-original draft preparation, F.W. and K.; writing-review and editing, F.W. and K.; project administration, F.W.; funding acquisition, H.L. All authors have read and agreed to the published version of the manuscript.

Funding: The authors gratefully acknowledge the financial support provided by Bureau of Energy, Ministry of Economic Affairs, Taiwan. 
Conflicts of Interest: The authors declare no conflict of interest.

\section{References}

1. Chua, K.J.; Chou, S.K.; Yang, W.M. Advances in heat pump systems: A review. Appl. Energ. 2010, 87, 3611-3624. [CrossRef]

2. Franco, A.; Fantozzi, F. Optimal sizing of solar-assisted heat pump systems for residential buildings. Buildings 2020, 10, 175. [CrossRef]

3. Berntsson, T. Heat sources-technology, economy and environment. Int. J. Refrig. 2002, 25, 428-438. [CrossRef]

4. Okamoto, S. A heat pump system with a latent heat storage utilizing seawater installed in an aquarium. Energ. Build. 2006, 38, 121-128. [CrossRef]

5. Osterman, E.; Stritih, U. Review on compression heat pump systems with thermal energy storage for heating and cooling of buildings. J. Energ. Storage 2021, 39, 102569. [CrossRef]

6. Lam, J.C.; Chan, W.W. Energy performance of air-to-water and water-to-water heat pumps in hotel applications. Energ. Convers. Manag. 2003, 44, 1625-1631. [CrossRef]

7. Medrano, M.; Brouwer, J.; McDonell, V.; Mauzey, J.; Samuelse, S. Integration of distributed generation systems into generic types of commercial buildings in California. Energ. Build. 2008, 40, 537-548. [CrossRef]

8. Felius, L.C.; Hamdy, M.; Dessen, F.; Hrynyszyn, B.D. Upgrading the smartness of retrofitting packages towards energy-efficient residential buildings in cold climate countries: Two case studies. Buildings 2020, 10, 200. [CrossRef]

9. eQUEST. DOE2.com Homepage. Available online: http:/ / www.doe2.com (accessed on 1 August 2020).

10. Zhu, Y. Applying computer-based simulation to energy auditing: A case study. Energ. Build. 2006, 38, 421-428. [CrossRef]

11. Norouziasl, S.; Jafari, A.; Zhu, Y. Modeling and simulation of energy-related human-building interaction: A systematic review. J. Build. Eng. 2021, 44, 102928. [CrossRef]

12. Yezioro, A.; Dong, B.; Leite, F. An applied artificial intelligence approach towards assessing building performance simulation tools. Energ. Build. 2008, 40, 612-620. [CrossRef]

13. Ascione, F.; Bianco, N.; Iovane, T.; Mastellone, M.; Mauro, G.M. Conceptualization, development and validation of EMAR: A user-friendly tool for accurate energy simulations of residential buildings via few numerical inputs. J. Build. Eng. 2021, 44, 102647. [CrossRef]

14. Choi, J.H. Investigation of the correlation of building energy use intensity estimated by six building performance simulation tools. Energ. Build. 2017, 147, 14-26. [CrossRef]

15. Cannavale, A.; Martellota, F.; Fiorito, F. Novel technologies to enhance energy performance and indoor environmental quality of buildings. Buildings 2021, 11, 303. [CrossRef]

16. Sanaye, S.; Meybodi, M.A.; Chahartaghi, M. Modeling and economic analysis of gas engine heat pumps for residential and commercial buildings in various climate regions of Iran. Energ. Build. 2010, 42, 1129-1138. [CrossRef]

17. Kulcar, B.; Goricanec, D.; Krope, J. Economy of exploiting heat from low-temperature geothermal sources using a heat pump Energ. Build. 2008, 40, 323-329. [CrossRef]

18. Miglani, S.; Orehounig, K.; Carmeliet, J. Integrating a thermal model of ground source heat pumps and solar regeneration within building energy system optimization. Appl. Energ. 2018, 218, 78-94. [CrossRef]

19. Lygnerud, K.; Ottosson, J.; Kensby, J.; Johansson, L. Business models combining heat pumps and district heating in buildings generate cost and emission savings. J. Energy 2021, 234, 121202. [CrossRef]

20. Bellanco, I.; Fuentes, E.; Vallès, M.; Salom, J. A review of the fault behavior of heat pumps and measurements, detection and diagnosis methods including virtual sensors. J. Build. Eng. 2021, 39, 102254. [CrossRef] 